\title{
PIONEER
}

VOLUME 13, Issue 2, December 2021: 187 - 196

\section{EMPOWERING SPEAKING SKILLS THROUGH SPEAKING ASSESSMENT IN THE PROCESS OF ELT IN THINK-E COURSE}

\author{
Amy Krisdiana* \\ Universitas Islam Majapahit, Indonesia \\ amykrisdiana@unim.ac.id
}
*Corresponding author: amykrisdiana@unim.ac.id
Received : October 30, $2021 \quad$ Revised : December 28, 2021
Accepted : : Pecember 28, $2021 \quad$ Published :December 31, 2021

\begin{abstract}
There are some kinds of speaking assessments, the accuracy in choosing the type of assessment determines the success of the student in speaking English. This can be seen in Think$E$ course, Think- $E$ course is successful in choosing the type of assessment so that the students in Think-E course can speak English fluently. The aim of the study is to describe types of assessments used in the English language Teaching at Think-E course, and how this assessment affects the speaking skills of the students in the Think- $E$ course. The researcher focused on macro skills speaking because the teaching-learning process in Think-E uses communicative function according to situation, participants, and goals. The method used by the researcher is qualitative. The researchers collected the data through observation. The participants of this research were the students in Bee 2 class. The finding shows that there are three types of speaking assessment used in English language Teaching at the Think-E course, they are intensive assessment, responsive assessment, and interactive assessment. In conclusion, the assessment used in Think-E course affect the students dare to speak English and the students also get used to speaking English, so that they can speak English fluently.
\end{abstract}

Keywords: English language teaching, speaking assessment, speaking skills

\section{INTRODUCTION}

Think-E is a course that concerns in speaking skills. Speaking skill is important for young learners because their brain's characteristic is good for getting a new language. Think-E is always successful to make students speak English. Think-E is an English course for young learners and is a homey course because there is no classroom setting so the students will feel comfortable with the teacher and fun with the teaching-learning process. There are some active learnings in Think-E, they are group discussion, presentation, problem-solving, and exploration. Besides, there are five grades in Think$E$, they are pre-bee (fun bee), Bee 1, Bee 2, Pre-International 1, and Pre-International 2. 
(Brown \& Lee, 2015) said that speaking skills have two criteria, as likes listening skills, they are micro-skills and macro skills. When someone produces smaller pieces of language such as phonemes, morphemes, words, collations, and phrasal units, it is called a macro skill. Meanwhile, macro skills focus on the larger elements such as fluency, discourse, communicative function, cohesion, non-verbal communication and strategic choices. The teaching-learning process in Think-E includes macro skills speaking because its teaching-learning process uses communicative function according to situation, participants, and goals. They also convey facial features, kinesics, body language and other nonverbal cues along with verbal language. When the teacher says something, the students will respond to what the teacher says. Because the learners are young, the teacher uses pictures to teach English. Usually, the teacher shows the pictures and students answer based on the pictures. The teacher also uses some games and role-play when they teach English so the learners can understand the material easily. Based on the explanation, we know about types of assessment in speaking, but we do not know what speaking assessment that Think-E uses. Thus, this article will explain what types of assessment that Think- $E$ uses and the effects of the speaking assessment itself.

\section{REVIEW OF LITERATURE}

\section{Assessment}

Teaching is a process for a learner to learn something new with the help from the teacher. Teachers help the students learn something new by explaining the material, giving instruction, and providing with the language. Thus, the teacher must be creative and able to manage the classroom well to make the students have a good understanding of the given material. To measure the student's understanding, assessments are needed. Soliha, as cited in (Swastika et al., 2020)) said that if the teacher wants to achieve the learning goals, the assessment used by teacher to control their students' learning progress should be authentic and determined by the instructional objective of the program. According to Mousavi in (Brown \& Abeywickrama, 2019), assessment is the process for assessing or measuring a person's level of understanding. Assessment is an ongoing process that includes various methodologies in measuring one's abilities. The teacher will subconsciously assess students' abilities when students respond to teacher questions, comment, or try new words or structures. Hartoyo, as cited in (Wijayanti, 2019) also 
stated that every teacher has the ability to measure the student's intelligence, interest, aptitude, and values by using the appropriate instruments so that the teacher must understand the concept of educational measurement as like as testing, assessment, examination, and evaluation. (Brown \& Abeywickrama, 2019) divided the assessment into two types, they are formal assessment and informal assessment. In informal assessment the teacher give the students comment or responses, informal assessment usually unplanned in the form of feedback given to the students. Formal assessments are exercises or procedures that occurs periodically and it specially designed to utilize skills and knowledge, it is systematic and planned. Tests are formal assessments, but of all formal assessment is testing. The test is a method to measure a person's ability, knowledge, and performance in a particular field, and it usually relative constrained by time.

\section{Speaking Assessment}

(Zaim et al., 2020) said when the teacher gives the students a speaking assignment, the teacher conducts an assessment directly when the students interact orally. The teacher must determine several indicators of speaking skills, the teacher also has to create a model of authentic speaking skills that are suitable for the teacher's need. According to (Brown \& Lee, 2015), assessment in speaking can be observed, recorded, and measured. There are three criteria in designing the assessment procedure of speaking, they are: a) determining the category of speaking performance (from imitative to extensive), b) describing the macro or micro-skills to be assessed, c) the spoken language genre which will be assessed. When the assessment indicators made by the teacher are more specific in showing these three criteria, the teacher will make a valid and reliable assessment procedure. That statement is supported by (Putra, 2017), who stated that the teacher needs several criteria to assess speaking ability. There are several aspects that must be considered by the teacher, namely aspect of accent, grammar, vocabulary, fluency, and understanding. Based on these aspects, the teacher will know how to correct the students' mistake in pronunciation, punctuation, grammar, and word selection. Think-E course use their own scoring rubrics to assess the students called target level. Here is the scoring rubrics used by Think-E. 
Table 1. Target Level of Speaking for Pre-bee, Bee 1, Bee 2

\begin{tabular}{lcl}
\hline $\begin{array}{l}\text { Excellent } \\
90-100 \% \text { target achieved }\end{array}$ & $90-100$ & $\begin{array}{l}\text { Students can achieve the target without teacher help, the } \\
\text { exploration of the students in terms of using the target language } \\
\text { in various situations. }\end{array}$ \\
$\begin{array}{l}\text { Very good } \\
80-90 \% \text { target achieved }\end{array}$ & $82-89$ & $\begin{array}{l}\text { Students can achieve the target without teacher help } \\
\text { Good }\end{array}$ \\
$70-80 \%$ target achieved & $72-81$ & $\begin{array}{l}\text { Students can achieve the target with a little help (using } \\
\text { question) }\end{array}$ \\
$\begin{array}{l}\text { Fair } \\
60-70 \% \text { target achieved }\end{array}$ & $60-71$ & Students can achieve the target with help (need to be translated) \\
\hline
\end{tabular}

Table 2. Target level of Speaking for Pre-International 1 and Pre-International 2

\begin{tabular}{lll}
\hline $\begin{array}{l}\text { Excellent } \\
90-100 \% \text { target achieved }\end{array}$ & $90-95$ & $\begin{array}{l}\text { students are able to do presentation/ tell a story in a good plot } \\
\text { (general to detailed) } \\
\text { students are able to do presentation/ tell a story in a good } \\
\text { grammar. } \\
\text { students are able to present clearly and in good pronunciations }\end{array}$ \\
\hline $\begin{array}{l}\text { Very good } \\
80-90 \% \text { target achieved }\end{array}$ & $82-89$ & $\begin{array}{l}\text { students are still helped in arranging the plot of presentation/ a } \\
\text { story } \\
\text { students are able to do presentation/ tell a story in a good } \\
\text { grammar } \\
\text { students are able to present clearly and in good pronunciations }\end{array}$ \\
& & $\begin{array}{l}\text { students are able to do simple and general presentation (no } \\
\text { detailed information) } \\
\text { students still make some mistakes in grammar }\end{array}$ \\
Good & $72-81$ & $\begin{array}{l}\text { students are able to do simple and general presentation (no } \\
\text { detailed information) } \\
\text { students still often make mistakes in grammar }\end{array}$ \\
\hline $\begin{array}{l}\text { Fair } \\
60-70 \% \text { target achieved }\end{array}$ & $60-71$ & $\begin{array}{l}\text { students don't apply correct grammar in either presentation or } \\
\text { daily speaking }\end{array}$ \\
\hline $\begin{array}{l}\text { Inadequate } \\
\text { (target not achieved) }\end{array}$ & - &
\end{tabular}

\section{Basic Types of Speaking Assessment}

According to Brown and Abeywickrama as cited in (Rahmawati \& Ertin, 2014), they classified the basic types of speaking assessment as the followings:

a. Imitative

Imitative means that the students imitate a word or phrase or possibly a sentence.

In imitative assessment, the students are interested only in what is traditionally labelled pronunciation. Two tasks include imitative assessment, they are word repetition task and phonepass test.

b. Intensive

Intensive is assessment context that the students produce of short stretches of oral language designed to demonstrate competence in narrow grammatical, phrasal, lexical, or phonological relationships. Some tasks include intensive assessment, they are direct response task, Read- Aloud task, sentence or dialogue completion 
tasks, oral questionnaire task, picture-cued task, and translation (of limited stretches of discourse) task.

c. Responsive

Responsive assessment includes interaction, so the students have to present short conversations, standard greetings, small talk, simple requests and comments and the like. Here, the task that includes responsive speaking, is question and answer, Giving instructions and direction, paraphrasing, a test of spoken English.

d. Interactive

Interactive assessments are in interpersonal exchange, oral production can become pragmatically complex with the need to speak casual register and use colloquial language, ellipsis, slang, humor, and other sociolinguistic conventions, so in interactive assessment, the students have to be active in speaking, they also have to speak casual register and use colloquial language. The task in interactive assessment is interview task, roleplay, games, oral proficiency interview (OPI).

e. Extensive

Extensive assessment deals with (monologue) oral production tasks. The students have to do a speech, oral presentation, storytelling in extensive assessment. Some tasks that include extensive assessment, are picture cued storytelling, oral presentation, translation (of extended prose).

\section{METHOD}

In this research, the researchers use the qualitative method to analyze the data in attempt to describe the activity and conversation between teacher and students in teaching ang learning process. According to Creswell as cited in (Shakouri, 2014)), qualitative research is an effort of gaining the data based on interaction between individuals, in this case between researcher and participants of the research. Zohrabi as cited in (Mohajan, 2018) also stated that qualitative research is an approach related to social action which includes the use of diaries, journals, interviews, classroom observation to gain understanding, interpretation, and analysis data visually and textually. (Creswell \& Creswell, 2018) stated that there are some steps of data collection of qualitative research, they are; observation, interviews, visual materials, setting the boundary of the study and 
recording. To analyses this research, the researchers use observation to collect the data. The researchers came to the class and collect the data through observation.

\section{FINDINGS AND DISCUSSION}

\section{Findings}

In this case the researcher showed the data of speaking assessment through the conversation between the teacher and the students. The researcher classified the data of speaking assessment based on the types of assessment.

\section{a. Interactive Assessment $1^{\text {st }}$ conversation}

Teacher : (showing a picture of an object in the bathroom) What is it?

Student : Shower

Teacher : (showing a picture of an object in the kitchen) What is it?

Student : Cutting board

\section{$2^{\text {nd }}$ conversation}

Teacher : (showing a picture of an object in the bathroom) What is it?

Students : Bathroom

Teacher : (showing a picture of an object in the bathroom) What is it?

Students : Soap

Teacher : (showing two pictures of objects in the bathroom) Where is the soap?

Students : The soap is in the bathroom.

\section{$3^{\text {rd }}$ conversation}

Teacher : (writing down the song lyrics) Do you know this song (Que sera sera)?

Student : Yes, Miss... on the television, there is this song.

Teacher : Okay.... Write down this song first, later we will read the song Together. After this, you have to read the song one by one.

Students : Okay, Miss... (then the students read "Que sera- sera" song one by one).

\section{b. Responsive Assessment}

\section{$4^{\text {th }}$ conversation}

Teacher : The tab is full of water. What do you need?

Students : Water dipper.

Teacher : Water dipper... very good, so make a sentence.

Students : I need a water dipper to take the water.

Teacher : Excellent!

\section{$5^{\text {th }}$ Conversation}

Teacher : Miss Lusy has a picture... you cannot show it. Later when your friend comes forward and your friend will say something about the thing, then you have to guess it. Okay.

Students : Okay miss Lusy. 


\section{c. Interactive Assessment $6^{\text {th }}$ Conversation}

Teacher : (shaking hand) Good afternoon, Viona,

Students : Good afternoon, Miss.

Teacher : How are you today?

Students : I am fine, thank you, and you?

Teacher : Very well, thank you.

\section{$7^{\text {th }}$ Conversation}

Teacher : (showing a picture of shampoo) What is it?

Students : Shampoo

Teacher : Where do you put it?

Students : In the bathroom

Teacher : Why do you use it?

Students : To clean my hair

Teacher : When do you use it?

Students : When my hair is dirty

\section{$8^{\text {th }}$ Conversation}

Teacher : Later, try to make a sentence about the thing that I mentioned. Do you understand? (showing a picture of an object) What is it?

Students : Bolster

Teacher : Try to make a sentence!

Students : I use bolster to lay down my head.

Teacher : (showing a picture of an object). What is it?

Students : Pillow. I use a pillow to hug.

Teacher : (showing a picture of an object) What is it?

Students : Desk. I use the desk to keep my book

Teacher : (showing a picture of an object) What is it?

Students : Chopsticks. I use chopsticks to take a noodle.

\section{$9^{\text {th }}$ Conversation}

Teacher : What color is your pillow?

Students : Pink, Miss.

Teacher : Do you like pink?

Students : Yes, Miss.

\section{Discussion}

Related to the types of assessment used by teachers in teaching speaking skills, the finding of this study is similar to the findings of the research conducted by (Jannah \& Hartono, 2018). In the previous research, it showed that there are three types that used by the teacher, namely intensive speaking assessment, responsive speaking assessment and interactive speaking assessment. In this research, the teacher at Think-E also used intensive speaking assessment, responsive speaking assessment and interactive speaking assessment. Although the types of speaking assessment is similar to the previous research, 
the activity of performance based assessment used by teacher is different. In the previous research, it showed that the activity used by teacher; such as: word repetition task, read a load task, sentence/ completion task, picture cued task, question and answer task, giving direction/ instruction task, role play, discussion, and conversation. Meanwhile, in this research, the activity used by teacher at Think- E; such as: picture cued task. read a loud task, question- answer task, giving instruction and direction, and interview. The teacher at Think-E mostly uses picture cued task. question- answer task, giving instruction and direction activity as the assessment of speaking skills while previous research mostly used role play activities. The teacher at Think-E used picture cued elicitation of comparative because picture-cued elicitation of comparative made it easier for the students to get the vocabulary. Picture-cued tasks helped the student memorize the vocabulary when the teacher used the picture to give speaking assessments for their students. Reading aloud task helped the teacher know the pronunciation of their students. When the students did wrong pronunciation, the teacher would correct it, so the students will remember it. When the teacher gave a question for the student, then the students answer it, the teacher would give respond with "good, very good and excellent". It would make the students happy and trigger their interest. Giving instruction and direction helped the students produce words or sentences. They tried to make a sentence to develop their English-speaking ability.

The interview helped the teacher know the speaking ability of the students. Interactive speaking assessment was done by using an interview. There are four stages in the interview, they are warm-up, level choice, probe and wind down. Each stage has its own function. Warm up stage makes the students comfortable when they speak English with the teacher. Level check stages helps the teacher know the students' speaking ability. Level check is also used by the teacher to stimulate the students' vocabulary. Probe helped the teacher know about the students understanding of the material that the teacher taught. In Probe, the teacher knew the English-speaking ability of the students. The wind of is the last stage of interactive assessment. The function of wind of is to encourage the students to relax in learning the material with a few questions.

Based on the explanation, it shows that the speaking assessment used by the Think- $E$ course made the students dare to speak English. Moreover, the selection of assessment also affects the students to get used to speaking English, so that the students can speak English fluently. 


\section{CONCLUSIONS AND SUGGESTIONS}

\section{Conclusions}

Based on the discussion, it is concluded that three types of speaking assessment were applied in Think-E course, namely intensive speaking assessment, responsive speaking assessment and interactive speaking assessment. These three types of speaking assessment are effective in helping the student speak English fluently.

\section{Suggestions}

As a result of speaking assessment used by Think-E, it suggested to the readers that speaking assessment can affect the students' speaking ability so that the teacher must choose the suitable speaking assessment. As a teacher, we must know the suitable assessment for young learns. The assessment that makes the students enjoy, comfort, and make them enthusiastic when they learn English especially in speaking skills.

\section{REFERENCES}

Brown, H. D., \& Abeywickrama, P. (2019). Language Assessment: Principles and Classroom Practices 3rd Edition (Third Edition). Pearson Education ESL.

Brown, H. D., \& Lee, H. (2015). Teaching by principles: An interactive approach to language pedagogy (Fourth edition). Pearson Education.

Creswell, J. D., \& Creswell, J. W. (2018). Research Design: Qualitative, Quantitative, and Mixed Methods Approaches (fifth edition). SAGE Publication.

Jannah, W., \& Hartono, R. (2018). Students' Speaking Assessment Used by English Teachers Based on the 2013 Curriculum. English Education Journal (EEJ)Universitas Negeri Semarang, 8(3), 359-369.

Mohajan, H. K. (2018). QUALITATIVE RESEARCH METHODOLOGY IN SOCIAL SCIENCES AND RELATED SUBJECTS. Journal of Economic Development, Environment and People, 7(1), 23. https://doi.org/10.26458/jedep.v7i1.571

Putra, A. S. (2017). Channing: Journal of English Language Education and Literature, Vol. II No. 1 2017. 1, 22.

Rahmawati, Y., \& Ertin, E. (2014). DEVELOPING ASSES SMENT FOR SPEAKING. IJEE (Indonesian Journal of English Education), 1(2), 199-210. 
Shakouri, N. (2014). Qualitative Research: Incredulity toward Metanarrativeness. Journal of Education and Human Development, 3, 10.

Swastika, P. A., Miranti, R. R., \& Nur, M. R. O. (2020). The Analysis of Speaking Assessment Types in Textbook "When English Rings a Bell Grade VII." Jurnal Studi Guru Dan Pembelajaran, 3(2), 167-173. https://doi.org/10.30605/jsgp.3.2.2020.262

Wijayanti, D. N. (2019). English Teachers' Understanding of Language Assessment. Journal of English Teaching and Learning Issues, 2(2), 93-114. https://doi.org/10.21043/jetli.v2i2.5841

Zaim, M., Refnaldi, R., English Language Education, Universitas Negeri Padang, Indonesia, refnaldi@yahoo.com, Arsyad, S., \& Prof. at English Department, Universitas Bengkulu, Indonesia, safnilarsyad@gmail.com. (2020). Authentic Assessment for Speaking Skills: Problem and Solution for English Secondary School Teachers in Indonesia. International Journal of Instruction, 13(3), 587-604. https://doi.org/10.29333/iji.2020.13340a 